\title{
Correlation between foot type and posture for the elderly
}

\author{
Kyungock $\mathrm{Yi}^{1 *}$, Namhee Kim ${ }^{2}$ \\ From 4th Congress of the International Foot and Ankle Biomechanics (i-FAB) Community \\ Busan, Korea. 8-11 April 2014
}

The purpose of this study was to identify the correlation between foot type and posture. Subjects were 49 elderly people from a Catholic Church in the Seoul area. 13 subjects were men, and 36 were women. Questionnaire was used to identify injuries, blood pressure, history and location of pain, wallet carrying habits for men (left or right side). Resting Calcanel Stance Position (RCSP) was used to identify foot type (pes planus, pes rectus, pes cavus), $\mathrm{F} / \mathrm{F}$ to $\mathrm{R} / \mathrm{F}$ and three-dimensional pelvic deviation were also measured,grip strength and posture (sagittal plane \& coronal plane). SPSS 18 was used for statistical analysis, along $\mathrm{x}^{2}$ (with Scheffe for post-hoc), and Kenndall's tau_b for the correlation.

1. Foot Deformity

a) $65 \%$ of test subjects had normal feet. $69 \%$ of elderly men and $64 \%$ of elderly women were normal.

b) $21 \%$ of elderly women had pes cavus.

c) There was a higher incidence of pes cavus and F/F to $\mathrm{R} / \mathrm{F}$ angle in the right foot compared to the left.

2. Correlation between foot type and posture

There was a correlation between left foot type and both sagittal postural deviation and coronal shoulder deviation. Subjects with left foot pes planus also exhibited a rearward postural deviation and a left downward sloping shoulder deviation.

There were correlation between deviation in the shoulder, shoulder blade, and pelvis. Thus, subjects with one type of deviation are likely to have corresponding deviations in the other two areas.

For men, shoulders and shoulder blades tilted in the same direction as the pelvis: e.g. Right downward sloping shoulders / shoulder blades corresponded to a right downward sloping pelvis.

Men's pelvis deviated towards their wallet-carrying side in the transverse plane: e.g. men who habitually carried

${ }^{1}$ Human Movement Study, Ewha Womans University, Seoul, Korea, 120750 Full list of author information is available at the end of the article their wallet in their left pocket had a rearward deviation in their left pelvis and vice versa.

There was a negative correlation between grip strength and injury history. Subjects with stronger grip strength had less injuries and vice versa.

There was a positive correlation between injury history and sagittal postural deviation.

\section{Authors' details}

'Human Movement Study, Ewha Womans University, Seoul, Korea, 120750.

${ }^{2}$ Hanbuk University, Donduchun,Kyuggido, 473777, Korea.

Published: 8 April 2014

\section{References}

1. Kyungock Yi, Kim N, Kim Y: The Differences in Foot Type According to Major in Left and Right Foot for Female College Students. Korean Journal of Sport Biomechanics 2012, 22(2):229-236.

2. Kyungsook Kim, et al: The Effects of Exercise on Physical and Rear Foot Deformities in Gifted Youth Athletes. Journal of Korean Education Association for Girls and. Woman 2011, 2:181-193.

doi:10.1186/1757-1146-7-S1-A89

Cite this article as: $\mathrm{Yi}$ and Kim: Correlation between foot type and posture for the elderly. Journal of Foot and Ankle Research 2014 7(Suppl 1):A89.

Submit your next manuscript to BioMed Central and take full advantage of:

- Convenient online submission

- Thorough peer review

- No space constraints or color figure charges

- Immediate publication on acceptance

- Inclusion in PubMed, CAS, Scopus and Google Scholar

- Research which is freely available for redistribution

Submit your manuscript at www.biomedcentral.com/submit
() Biomed Central 